DEPARTMENT OF THE INTERIOR

Franklin K. LANE, Secretary

United States Geological Survey

George Otis Smith, Director

\title{
Bulletin 621
}

\section{CONTRIBUTIONS TO ECONOMIC GEOLOGY}

(SHORT PAPERS AND PRELIMINARY REPORTS)

\section{5}

PART II.-MINERAL FUELS

M. R. CAMPBELL AND DAVID WHITE GEOLOGISTS IN CHARGE

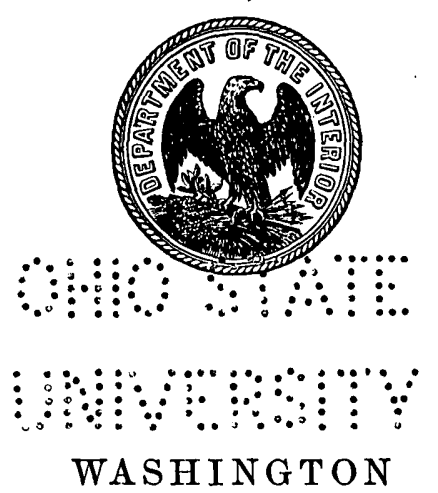

GOVERNMENT PRINTING OFFICE 1916 


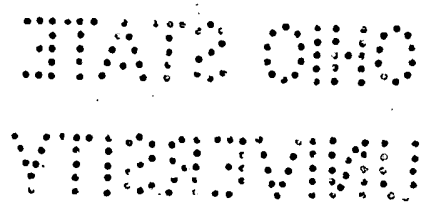




\section{CONTENTS.}

[Arranged according to subjects.]

Petroleum and naturil gas:

The Fealdton oil field, Carter County, Okla., by C. H. Wegemann and

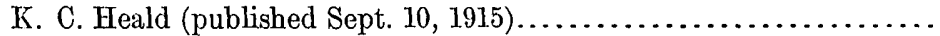

Loco gas field, Stephens and Jefferson counties, Okla., by C. H. Wegemann (published Aug. 30, 191.5).................................

The Duncan gas field, Stephens County, Okla., by C. H. Wegemann (published Aug. 30, 1915).

A reconnaissance in Palo Pinto County, Tex., with special reference to oil and gas, by C. H. Wegemann (published Sept. 11, 1915).

Possibilities of oil in the Porcupine dome, Rosebud County, Mont., by C. F. Bowen (published Sept. 24, 1915).

The Lawton oil and gas field, Oklahoma, by C. H. Wegemann and R. W.

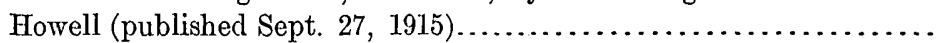

Anticlines in the Clinton sand near Wooster, Wayne County, Ohio, by C..A. Bonine (published Oct. 8, 1915).

A reconnaissance for oil near Quanah, Hardeman County, Tex., by C. H. Wegemann (published Oct. 9, 1915).

Oil and gas near Basin, Big Horn County, Wyo., by C. T. Lupton (pub-

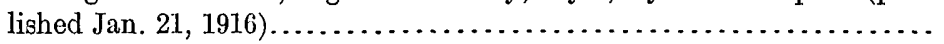

Geology and oil prospects of Cuyama Valley, Cal., by W. A. English (published Feb. 23, 1916).

Structure of the Berea oil sand in the Summerfield quadrangle, Guernsey, Noble, and Monroe counties, Ohio, by D. D. Condit (published Feb. 3, 1916)....

Structure of the Berea oil sand in the Woodsfield quadrangle, Belmont, Monroe, Noble, and Guernsey counties, Ohio, by D. D. Condit (pub-

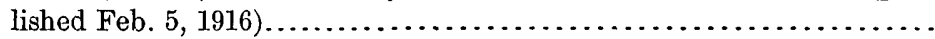
COAL:

Field apparatus for determining ash in coal, by C. E. Lesher (published

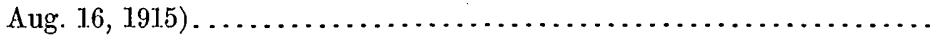

The Orofino coal field, Clearwater, Lewis, and Idaho counties, Idaho, by

C. T. Lupton (published Oct. 9, 1915)........................

Geology and coal resources of northern Teton County, Mont., by Eugene

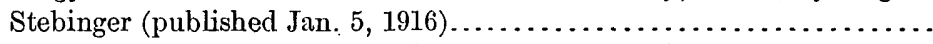

Analyses of coal samples from various parts of the United States, by M. R. INDEX

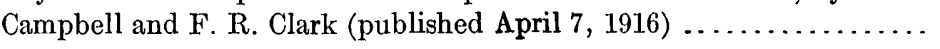




\section{ILLUSTRATIONS.}

Plate I. Field apparatus for determining ash in coal...................

II. $A$, Weighing a sample of coal for determination of ash; $B$, Apparatus packed in carrying case, with gasoline can removed to show in-

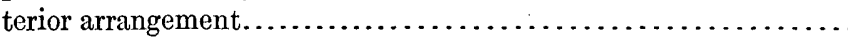

III. Map of the Healdton oil field, Oklahoma....................

IV. Logs of wells along north line of secs. 8 and 9, T. 4 S., R. 3 W., Heald-

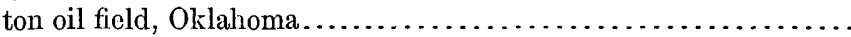

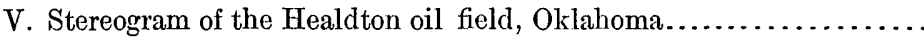

VI. Map of the Loco gas field, Stephens County, Okla...............

VII. Logs of wells in the Loco gas field, Stephens County, Okla........

VIII. Map of the Duncan gas field, Stephens County, Okla.............

IX. Logs of wells in the Dúncan gas field, Oklahoma, and index map showing location of wells................................

X. Map of the Porcupine dome, Rosebud County, Mont.............

XI. Map of the Lawton oil and gas field and adjacent territory, Comanche

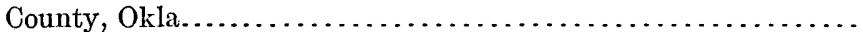

XII. Logs of 10 wells in the Lawton field, Oklahoma, drilled to a depth of

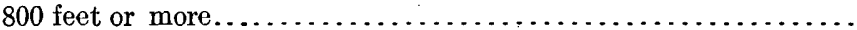

XIII. Map of Wooster oil and gas field, Wayne County, Ohio............

XIV. Map of part of Hardeman County, Tex........................

XV. Geologic sketch map and sections of northern Teton County, Mont..

XVI. Map showing coal resources and sections of the coal beds. of northern

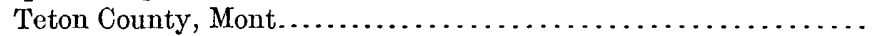

XVII. Geologic map of the Basin oil and gas field and adjacent areas, Wyom-

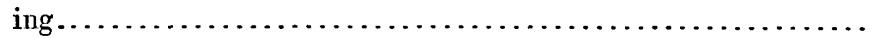

XVIII. Detailed map of the Basin oil and gas field, Wyoming, showing position of wells, elevations, and some topography............ 188

XIX. Geologic map of Cuyama Valley, Cal...................... 194

$\mathrm{XX}$. Table showing local lithologic variations of formations in Cuyama

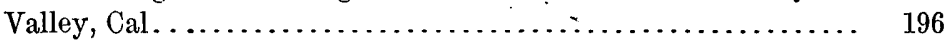

XXI. Geologic sections across Cuyama Valley, Cal................ 208

XXII. Farm map of Summerfield quadrangle, Ohio, with structural contours and well locations........................... In pocket.

XXIII. Map of Summerfield quadrangle, Ohio, showing locations of oil and gas pools.................................... In pocket.

XXIV. Farm map of Woodsfield quadrangle, Ohio, with structural contours and well locations.................................... In pocket.

XXV. Map of Woodsfield quadrangle, Ohio, showing locations of oil and

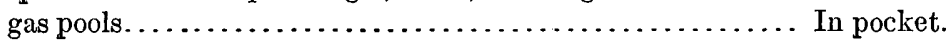

Figure 1. Pan support for balance.............................. 3

2. Barthel's gasoline blast lamp........................... 4

3. Index map of the oil and gas fields of Oklahoma............... 15

4. Index map of Texas showing area in Palo Pinto County......... 52

5. Map of anticlinal structure north of Palo Pinto, Tex.......... 5 
Page.

Figure 6. Index map of Montana showing location of the Porcupine dome... 61

7. Map of Idaho showing location of Orofino coal field........... 100

8. Map showing coal prospects and geology of Orofino coal field, Idaho. 102

9. Index map of Oklahoma and northern Texas showing location of area near Quanah................................. 109

10. Index map showing location of northern Teton County, Mont..... 118

11. Index map of Wyoming showing position of the Basin oil field... . 157

12. Index map of a part of California....................... 192

13. Index map showing location of Summerfield and Woodsfield quadrangles and other areas in eastern Ohio and neighboring parts of West Virginia and Pennsylvania for which structural maps of oil sands have been prepared.........................

14. Generalized section of rocks that crop out in the Summerfield quadrangle, Ohio....................................

15. Generalized geologic section showing oil sands of Summerfield

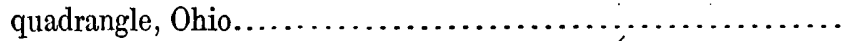

16. Generalized section of rocks exposed in the Woodsfield quadrangle, Ohio...........................................

17. Generalized section showing oil sands and accompanying beds in Woodsfield quadrangle, Ohio...........................

\section{INSERTS.}

Laboratory distilling flask analyses made to determine the refining qualities of Heald ton crude oil .......................................... 26

Various classifications of the rocks in reports on the Bighorn Basin, Wyo..... 166 



\title{
CONTRIBUTIONS TO ECONOMIC GEOLOGY, 1915.
}

\author{
PART II.-MINERAL FÜELS.
}

M. R. Campbell and David White, Geologists in Charge.

\section{INTRODUCTION.}

This volume is the ninth of a series that includes Bulletins 316,341 , $381,431,471,531,541,581$, and 621, "Contributions to economic geology (Part II)" for 1906, 1907, 1908, 1909, 1910, 1911, 1912, 1913, and 1915, respectively. Previous to 1906 the annual "Contributions" consisted of one part only and papers on mineral fuels were included with the papers on metals and nonmetals except fuels in a single volume. These earlier volumes are Bulletins 213, 225, 260, and 285, for $1902,1903,1904$, and 1905, respectively. Beginning with the present volume the year included in the title will be the year of publication ${ }^{1}$ instead of the year in which the field work reported was done. This volume is therefore dated 1915, and there will be no volume entitled "Contributions to economic geology, 1914."

As the subtitle indicates, the papers included are of two classes(1) short papers giving comparatively detailed descriptions of occurrences that have economic interest but are not of sufficient importance to warrant a more extended description; (2) preliminary reports on economic investigations the results of which are to be published later in more detailed form. These papers are such only as have a direct economic bearing, all topics of purely scientific interest being excluded. Each paper has been issued as an advance chapter as soon as it was ready.

Brief abstracts of the Survey's publications of the year are given in the annual report of the Director. The complete list of Survey publications affords, by means of finding lists of subjects and of authors, further aid in ascertaining the extent of the Survey's work in economic geology.

1 Owing to unexpected delays it has been impossible to publish all the chapters of the present volume within the year 1915. 
